Received: 04.02 .2020

Revised: 27.02 .2020

Accepted: 06.03.2020

DOI: $10.17804 / 2410-9908.2020 .2 .038-060$

\title{
A STUDY OF BORIDING METHODS, AN ANALYSIS OF THE STRUCTURE AND PROPERTIES OF THE OBTAINED COATINGS
}

\author{
N. B. Pugacheva ${ }^{\text {a) }}$ and T. M. Bykova ${ }^{\text {b* }}$ \\ Institute of Engineering Science, Ural Branch of the Russian Academy of Sciences, \\ 34 Komsomolskaya St., Ekaterinburg, 620049, Russian Federation \\ a) (iD https://orcid.org/0000-0001-8015-8120 nat@imach.uran.ru; \\ b) (iD https://orcid.org/0000-0002-8888-6410 @ tatiana_8801@mail.ru \\ *Corresponding author. E-mail: tatiana_8801@mail.ru \\ Address for correspondence: 34 Komsomolskaya St., Ekaterinburg, 620049, Russian Federation \\ Tel.: +7 (343) 36230 43, fax: +7 (343) 3745330
}

The results of studying various boriding methods are presented, as well as an analysis of the structure and properties of boride coatings on steels of different chemical compositions. The features of the formation of these coatings and possible types of defects in them are analyzed. The results of studying the protective properties of boride coatings of different chemical and phase compositions are shown.

Keywords: coating, borides, microhardness, plastic deformation, diffusion.

\section{Acknowledgment}

The work was performed under the state assignment, theme No. AAAA-A18-118020790145-0.

\section{References}

1. Tarasov S.Yu., Trusova G.V., Kolubaev A.V., and Sizova O.V. Structural properties of boride coatings for triboengineering. Metal Science and Heat Treatment, 1995, vol. 37, pp. 257-260. DOI: 10.1007/BF01152230.

2. Maltseva L.A., Gervasiev M.A., Kutin A.B. Materialovedenie [Materials Science]. Ekaterinburg, Izd-vo UGTU-UPI Publ., 2007, 338 p. (In Russian).

3. Guzanov B.N., Kositsyn S.V., and Pugacheva N.B. Uprochnyayushchie zashchitnye pokrytiya $v$ mashinostroenii [Reinforcing Protective Coatings in Engineering Industry]. Ekaterinburg, Ural. Otd. Ross. Akad. Nauk Publ., 2003. (In Russian).

4. Pugacheva N.B., Zamaraev L.M., Trushina E.B., Gurchenko T.M., and Zamjatin A.N. The features of destruction by the diffusion boride coating on the carbon constructional steel in thermo-cycling under loading conditions. Uprochn. Tekhnol. Pokryt., 2011, no. 3, pp. 24-30. (In Russian).

5. Burnyshev I.N., Valiakhmetova O.M., and Mutagarova S.A. On the issue of steel borating. Vestn. IzhGTU, 2007, no. 4, pp. 124-127. (In Russian).

6. Mozberg R.K. Materialovedenie [Materials Science]. Moscow, Vysshaya Shkola Publ., 1991, 448 p. (In Russian).

7. Dombrovskiy Y.M., Stepanov M.S. New aspects of surface impregnation in powder environment. Vestnik of Don State Technical University, 2011, vol. 11 (8-1), pp. 1217-1221. (In Russian.).

8. Anfinogenov A.I., Chebykin V.V., Chernov Ya.B. Analysis of the development of chemical-thermal treatment of metals and alloys. Melts, 2005, no. 3. pp. 40-52. (In Russian). 
9. Voroshnin L.G., Mendeleeva O.L., and Smetkin V.A. Teoriya i tekhnologiya khimikotermicheskoi obrabotki [Theory and Technology of Chemical Thermal Treatment]. Moscow, Novoe Znanie Publ., 2010, 304 p. (In Russian).

10. Perspektivnye materialy. Struktura i metody issledovaniya [Promising Materials: Structure and Methods of Investigation, ed. by D.L Merson]. Tollyatti, Moscow, TGU-MISiS Publ., 2006, 536 p. (In Russian).

11. Malkova N.Yu. Disadvantages and advanced methods of chemical-thermal treatment. Advances in Current Natural Sciences, 2007, no. 12, pp. 106-107. (In Russian).

12. Gadalov V.N., Borsiakov A.S., Salnikov V.G., Kvashnin B.N., Zhelanova L.A. Special features of the structure and properties of boride diffusive layers, optimization of the technology for their production. Proceedings of the South-West State University. Technics and Technologies, 2012, no. 2 (1), pp. 73-77. (In Russian).

13. Kovenskiy I.M., Povetkin V.V. Metallovedenie pokrytiy [Metallography of Coatings]. M., Intermet Engineering, 1999, 296 p. (In Russian).

14. Borsyakov A.S., Gadalov V.N., Kolmykov V.I. Electrolysis borating of metals and alloys. In: Svarka i Rodstvennye Tekhnologii v Mashinostroenii i Elektronike [Welding and Cognate Processes in Mechanical Engineering and Electronics: Regional Collection of Scientific Papers]. Kursk, Kurskiy Gosudarstvennyy Tekhnicheskiy Universitet, 2002, iss. 5. (In Russian).

15. Nicholl A.R., Gruner H., Wuest G., Keller S. Future development in plasma spray coating. Mater. Sci. Technol., 1996, vol. 2, no. 3, pp. 214-219. DOI: 10.1179/mst.1986.2.3.214.

16. Teplykh A.M., Golovin E.D., Bataev V.A., Golkovsky M.G., Bataev A.A., Gontarenko A.S., Drobyaz E.A. Borating of low-carbon steel with the application of non-vacuum electronbeam processing technology. In: International Conference on Physical Mesomechanics, Computer Design and Development of New Materials: Proceedings, Tomsk, IFPM Publ., 2011, pp. 494-496. 17. Pugacheva N.B., Bykova T.M. The degree of breakdown of the cemented and borated surfaces on details of the cutting pair of the hydromechanical slot perforator. Obrabotka Metallov. Metal Working and Material Science, 2015, no. 1 (66), pp. 51-59. (In Russian). DOI: 10.17212/1994-6309-2015-1-51-59.

18. Butukhanov V.A., Markhasaev Yu.A., Markhasaev A.V. A protective diffusion coating after saturation with boron and vanadium on steels for forming tools. In: Electrical Engineering. Energy, Mechanical Engineering (EEM-2014): selected papers from The First International Scientific Conference of Young Scientists, in 3 sections, section 3, Novosibirsk, December 2-6 2014, Novosibirsk, Izd-vo NGTU Publ., 2014, pp. 194-198. (In Russian).

19. Shilyakin L.V., Veropakha D.N., Veropakha N.V. Method updating by liquid borides of steel products with the purpose of increase of their operational properties. Izvestiya VUZov. Sev.Kavkazsk. Region, 2014, no. 1. pp. 48-51. (In Russian).

20. Gun G.S., Krivoshchapov V.V., Chukin M.V., Adamchuk V.S., Tsun A.M. Uprochnyayushchie $i$ vosstanavlivayushchie pokrytiya [Strengthening and Recovering Coatings]. Chelyabinsk, Metallurgiya Publ., 1991, 160 p. (In Russian).

21. Sobachkin A.V., Yakovlev V.I., Loginova M.V., Dong Ya., Guriev A.M. Electric surfacing of wear resistant SHS-powder coating of working bodies of agricultural machines. In: Effect of External Influences on the Strength and Plasticity of Metals and Alloys: book of the International workshop articles, Barnaul, AltSTU publ., 2015, p. 104.

22. Nicholls J.R. Designing oxidation-resistant coating. JOM, 2000, vol. 52, no. 1, pp. 28-35. DOI: $10.1007 / \mathrm{s} 11837-000-0112-2$.

23. Keddam M., Chegroune R. A model for studying the kinetics of the formation of Fe2B boride layers at the surface of a gray cast iron. Appl. Surf. Sci., 2010, vol. 256, iss. 16, pp. 5025-5030. DOI: 10.1016/j.apsusc.2010.03.048.

24. Guriev A.M., Ivanov S.G., May Sh. The structure of boride coatings on steels for various purposes. In: Electrical Engineering, Energy, Mechanical Engineering (EEM-2014): selected 
papers from The First International Scientific Conference of Young Scientists, in 3 sections, section 3, Novosibirsk, December 2-6 2014, Novosibirsk, Izd-vo NGTU Publ., 2014, pp. 194-198. (In Russian).

25. Matijeviж B. Evaluation of Boride Layer Growth on Carbon Steel Surfaces. Metal Science and Heat Treatment, 2014, vol. 56, pp. 269-273. DOI: 10.1007/s11041-014-9744-7.

26. Guzanov B.N., Kositsyn S.V., and Pugacheva N.B. Reinforcing Protective Coatings in Mechanical Engineering. Ekaterinburg, URO RAN Publ., 2004, 242 p. (In Russian).

27. Filippov M.A., Kositsina I.I., Gervasiev M.A. Hardening and Protection of the Metal Surface. Ekaterinburg, UrB RAS, 2012, 234 p. (In Russian).

28. Pugacheva N.B. Current trends in the development of heat-resistant coatings based on aluminides of iron, nickel and cobalt. Diagnostics, Resource and Mechanics of Materials and Structures, 2015, iss. 3, pp. 51-82. DOI: 10.17804/2410-9908.2015.3.051-082. Available at: https://www.dream-journal.org/DREAM_Issue_3_2015_Pugacheva_N._B._051_082..pdf

29. Denisyuk A.K., Zagulyaeva S.V., Potutkina E.N. Structure of borided layers in carbon steel. Russian Engineering Research, 2011, vol. 31, pp. 191-192. DOI: 10.3103/S1068798X11020080.

30. Guryev M.A., Guryev A.M., Ivanov A.G., Ivanov S.G. Analysis of the influence of the nature of alloying elements in high alloy steels on the processes of complex multicomponent diffusion borating. International Journal of Applied and Fundamental Research, 2010, no. 5, pp. 155-157. (In Russian).

31. Pugacheva N.B., Bykova T.M., and Trushina E.B. The steel-basis structure influence on the diffuzion boride coatings structure and properties. Uprochn. Tekhnol. Pokryt., 2013, no. 4, pp. 3-7.

32. Kilic A., Kartal G., Urgen M., Timur S. Effects of electrochemical boriding process parameters on the formation of titanium borides. Surface Engineering and Applied Electrochemistry, 2013, vol. 49, iss. 2, pp. 168-175. DOI: 10.3103/S1068375513020051.

33. Bykova T.M. The influence of the chemical composition of the steel on the structure and properties of diffusion boride coatings. Cand. Thesis, Ekaterinburg, 2016. (In Russian).

34. Afanasyev A.A., Pogonin A.A., Stativko A.A. Microhardness of diffusion boride layers on steels as a qualitative indicator of the surface. Bulletin of Kharkov National Automobile and Highway University, 2008, no. 42, pp. 65-67. (In Russian).

35. Gadalov V.N., Borsyakov A.S., Salnikov V.G., Kvashnin B.N., Romanenko D.N., Lyakhov A.V. Diffuznye boridnye pokrytiya na zheleze, stalyakh i splavakh [Diffusion Borided Coatings on Iron, Steels, and Alloys]. M., Kurs, 2012. (In Russian).

36. Goncharov I.Yu., Druchinina O.A., Kamyshanchenko N.V., Kovaleva M.G., Kolpakov A.Ya. Influence of thickness of coating on reconditioning the surface of substrate deformed during microindentation. Deformatsiya i Razrushenie materialov, 2006, no. 5, pp. 30-34. (In Russian).

37. Pugacheva N.B., Bykova T.M. The structure and properties of gradient boride coatings on steels. In: Mechanics, Resource and Diagnostics of Materials and Structures: Sourcebook, 2016, pp. 210-211. (In Russian).

38. Tyurin A.G., Plotnikova N.V., Burov V.G., Veselov S.V., Golovin E.D. Surface-hardened materials fatigue cracking features. Nauchnyy Vestnik Novosibirskogo Gosudarstvennogo Tekhnicheskogo Universiteta, 2007, no. 4. pp. 93-98. (In Russian).

39. Pugacheva N.B., Pavlyshko S.V., Trushina E.B., Zamyatin A.N. Investigation of mass transfer during tribological interaction of alloyed steels. Journal of Friction and Wear, 2012, vol. 33, no. 3. pp. 208-216. DOI: 10.3103/S1068366612030099.

40. Denisyuk A.K., Zagulyaeva S.V., Potutkina E.N. Effect of borating conditions on structure and hardness of borating layer. Uprochn. Tekhnol. Pokryt., 2012, no. 2, pp. 29-31. (In Russian).

41. Lukyanonov D.S. The effect of residual macrostresses on the process of nucleation of quasibrittle cracks in thermal diffusion coatings. Uspekhi Sovremennogo Estestvoznaniya, 2011, no. 7. pp. 266-267. (In Russian). 
42. Borisenok G.V., Vasilyev L.A., Voroshnin L.G. et. al. Khimiko-termicheskaya obrabotka: spravochnik [Thermochemical Treatment of Metals and Alloys: reference book]. Moscow, Metallurgiya Publ., 1981, 424 p. (In Russian).

43. Pugacheva N.B., Mazaev E.S. Protective properties of high-temperature combined coatings. Fizika i Khimiya Obrabotki Materialov, 2001, no. 4. pp. 82-90. (In Russian).

44. Schlichting K.W. Padture N.P., Jordan E.H., Gell M. Failure modes in plazma-spraed thermal barrier coatings. Materials Science and Engineering, 2003, vol. A342, pp. 120-130. DOI: 10.1016/S0921-5093(02)00251-4. 
Подана в журнал: 04.02.2020

УДК 620.18.186:621.793.6

DOI: $10.17804 / 2410-9908.2020 .2 .038-060$

\title{
ИССЛЕДОВАНИЕ МЕТОДОВ БОРИРОВАНИЯ, АНАЛИЗ СТРУКТУРЫ И СВОЙСТВ ПОЛУЧАЕМЫХ ПОКРЫТИЙ
}

\author{
Н. Б. Пугачева ${ }^{\text {a) }}$, Т. М. Быкова ${ }^{\text {б)* }}$ \\ Институт машиноведения Уральского отделения Российской академии наук, \\ ул. Комсомольская, 34, г. Екатеринбург, Российская Федераџия \\ a) (iD https://orcid.org/0000-0001-8015-8120 nat@imach.uran.ru; \\ b) (iD https://orcid.org/0000-0002-8888-6410 @ tatiana_8801@mail.ru \\ *Ответственный автор. Электронная почта: tatiana_8801@mail.ru \\ Адрес для переписки: ул. Комсомольская, 34, г. Екатеринбург, Российская Федерация \\ Тел.: +7 (343) 362-30-43, факс: +7 (343) 374-53-30
}

Представлен аналитический обзор накопленного к настоящему времени опыта применения различных методов борирования, а также сравнительный анализ структуры и свойств получаемых боридных покрытий на сталях разного химического состава. Приведены результаты исследований защитных свойств боридных покрытий разного химического и фазового составов.

Ключевые слова: химико-термическая обработка, сталь, покрытие, бориды, микротвердость, диффузия, износостойкость, термоциклирование.

\section{1. Введение}

В настоящее время накоплен довольно большой научно-производственный опыт применения защитных покрытий в условиях разгара и интенсивного изнашивания. Термодиффузионное борирование может повысить долговечность деталей машин и инструмента в подобных условиях эксплуатации не менее чем в 2-3 раза [1]. При этом отмечается, что для практического использования независимо от класса сталей и типоразмеров упрочняемых деталей наиболее приемлемыми можно считать порошковые смеси на основе карбида бора [2]. Однако в зависимости от габаритов штамповой оснастки известные способы термодиффузионного насыщения имеют разную эффективность.

Качественной и количественной характеристиками процесса борирования являются толщина диффузионного слоя, распределение концентрации бора по толщине покрытия его фазовый состав и свойства (твердость, износостойкость и термическая стабильность). Строение боридных покрытий существенно зависит от состава насыщающей смеси, способа борирования, температуры, длительности процесса и состава стали. Все эти факторы влияют на конечный результат и определяют физико-механические свойства поверхностного слоя после борирования. [3]. Поэтому вопросы создания функционально-градиентных поверхностных слоев, обладающих высокими механическими, технологическими и специальными свойствами, привлекают особое внимание, что делает актуальными исследования, направленные на создание таких поверхностей различными методами борирования.

Цель работы - провести сравнительный анализ основных способов нанесения боридного покрытия, а также полученных разными авторами сведений о влиянии химического состава стали-основы на структуру боридных покрытий и их защитные свойства. 


\section{2. История разработки метода борирования сталей}

Возможность поверхностного насыщения железа и стали бором впервые была представлена Н. П. Чижевским. Ряд ценных эксплуатационных свойств, присущих борированному слою, привлек впоследствии к исследованию процесса насыщения поверхности стали бором многих отечественных и зарубежных исследователей [1-5]. Борированный слой отличается высокой твердостью и износостойкостью, с которыми не могут конкурировать другие способы химико-термической обработки (XТO). С помощью борирования возможно повышение износостойкости в 3-50 раз по сравнению с термообработкой и в 1,5-15 раз, по сравнению с традиционными способами ХТО. Борированию могут подвергаться стали перлитного, ферритного и аустенитного классов. В соответствии с агрегатным состоянием насыщающей среды при ХТО можно выделить три основных метода борирования: в твердых, жидких и газообразных средах. Борирование в обмазках (из паст) занимает промежуточное положение между борированием в твердых и жидких средах. В зависимости от состава обмазки, температуры процесса и способа нагрева этот способ борирования приближается

к одному из них.

Борирование в порошковых смесях применяют для штампов горячего деформирования [6-8]. Мелкий штамповый инструмент более эффективно упрочнять при термодиффузионном насыщении в порошковых смесях на основе карбида бора. Этот способ отличается простотой технологии, высоким качеством покрытий, широкими возможностями по регулированию температуры насыщения и составов получаемых покрытий. Порошковые смеси для насыщения составляют на основе чистых материалов или их соединений (активная составляющая), окиси алюминия (инертный наполнитель) и галоидного активатора (калий тетрафторборат $\mathrm{KF}_{4} \mathrm{~B}$ ) [9]. Применяют для твердого борирования температуру в пределах 800-1200 ${ }^{\circ} \mathrm{C}$. Время и температуру борирования выбирают в зависимости от требуемой глубины борированного слоя.

Для штампов массой 1000-1500 кг наиболее приемлемой считается технология борирования из обмазок (nacm), при ней существует возможность местного борирования отдельных участков поверхности детали, а также совмещения процесса насыщения с упрочняющей термической обработкой [10]. Экспериментальные работы по оптимизации составов борирующих обмазок показали необходимость присутствия в ней следующих компонентов:

- поставщиков активных атомов бора;

- добавок, стабилизирующих защиту от окисления;

- активаторов.

В качестве поставщика активных атомов бора в пастах применяется карбид бора. Последующий отжиг в защитной атмосфере при температурах (900-1050) ${ }^{\circ} \mathrm{C}$ в течение от 1 до 5 ч приводит к диффузионному насыщению поверхности деталей с получением достаточно качественных защитных слоев.

Приготовление борирующих паст (суспензий) предусматривает использование различных связующих материалов. Основная роль связующего материала заключается в разбавлении пасты до необходимой консистенции и удержании ее на обрабатываемых поверхностях. Причем после помещения детали в предварительно нагретую печь это вещество должно испаряться или выгорать без существенного влияния на состояние основных компонентов. Обмазка не должна спекаться на упрочняемой поверхности и должна легко удаляться после окончания процесса ХТО. Особым преимуществом таких обмазок можно считать возможность длительной защиты обрабатываемых поверхностей от окисления в обычной печной атмосфере без использования дополнительного защитного оборудования и оснастки, что очень важно для химико-термической обработки крупногабаритных штампов. Даже при температурах обработки свыше 1000 C доступ кислорода к обрабатываемой по- 
верхности предотвращен, и процесс борирования развивается без нарушений в соответствии с протекающими химическими реакциями.

В силу ряда технологических преимуществ (местное насыщение поверхности, упрощение технологии, ускорение процесса) этот метод нашел применение в промышленности, хотя по сравнению с насыщением в порошках воспроизводимость результатов несколько ниже [11-12]. Присутствие в обмазке некоторых окислов металлов способствует защите активных компонентов от взаимодействия с кислородом. Наилучшие результаты получены при введении в состав пасты окислов железа $\left(\mathrm{FeO}, \mathrm{Fe}_{2} \mathrm{O}_{3}, \mathrm{Fe}_{3} \mathrm{O}_{4}\right)$, которые резко повышают ее защитные свойства. При этом происходит не только предохранение активных компонентов от окисления при длительных высокотемпературных выдержках, но и облегчается отделение обмазки от упрочняемой поверхности после окончания химико-термической обработки. Несмотря на то, что разработанные борирующие пасты содержат сравнительно дефицитный компонент - карбид бора, промышленное освоение их не вызывает особых проблем, так как затраты карбида бора в этом случае значительно меньше, чем в случае порошкового борирования [13].

Наиболее распространенным является жидкостное электролизное борирование. В тигель с расплавленной бурой помещают обрабатываемую деталь (катод) и графитовый стержень (анод), через которые пропускают постоянный ток для создания процесса электролиза. Оптимальная температура борирования 920-950 ${ }^{\circ} \mathrm{C}$. Основным оборудованием являются печи-ванны с электрическим или газовым обогревом. В качестве насыщающей среды используют $\mathrm{Na}_{2} \mathrm{~B}_{4} \mathrm{O}_{7} \cdot 10 \mathrm{H}_{2} 0$, который при плавлении теряет воду и диссоциирует с образованием атомарного бора. Образующийся атомарный бор диффундирует в поверхность детали. Оптимальный режим борирования: плотность тока на катоде $0,15-0,20 \mathrm{~A} / \mathrm{cm}^{2}$, напряжение 2-14 В, температура 930-950 ${ }^{\circ} \mathrm{C}$, выдержка от 2 до 4 ч; при этом получается диффузионный слой толщиной $0,15-0,35$ мм $[14,15]$.

Повышение плотности тока, температуры и длительности процесса незначительно увеличивает толщину слоя при одновременном возрастании его хрупкости. Кроме того, повышение температуры приводит к уменьшению срока службы оборудования, увеличению расхода сырья и ухудшает структуру основного металла. Понижение температуры уменьшает скорость диффузии и замедляет процесс борирования.

Жидкостное (безэлектролизное) борирование можно проводить в любых печахваннах, обеспечивающих получение требуемой температуры. Обычно для этих целей применяют те же печи, что и для электролизного борирования. В качестве насыщающих сред используют расплавы на основе боратов щелочных металлов (преимущественно $\mathrm{Na}_{2} \mathrm{~B}_{4} \mathrm{O}_{7}$ ), в которые добавляют электрохимические восстановители: химически активные элементы (Al, $\mathrm{Si}, \mathrm{Ti}, \mathrm{Ca}, \mathrm{Mn}$, В и др.) или ферросплавы, лигатуры и химические соединения на их основе: ферромарганец (ФМн95), силикомарганец (СМн17), силикоцирконий (СиЦр50), карбид бора $\left(\mathrm{B}_{4} \mathrm{C}\right)$, карбид кремния $(\mathrm{SiC})$, силикокальций (CК25). Указанные вещества вводят в расплав в виде порошка с размером частиц 0,05-0,6 мм (в зависимости от природы и удельной массы восстановителя). Оптимальное содержание восстановителя в расплаве колеблется от 20 до 40 \% по массе. Для получения двухфазных слоев $\left(\mathrm{FeB}+\mathrm{Fe}_{2} \mathrm{~B}\right)$ можно рекомендовать следующие расплавы:

1. $60-70 \% \mathrm{Na}_{2} \mathrm{~B}_{4} 0_{7}+40-30 \% \mathrm{~B}_{4} \mathrm{C}$;

2. $80 \% \mathrm{Na}_{2} \mathrm{~B}_{4} 0_{7}+20 \% \mathrm{CK} 25$,

а для получения однофазных $\left(\mathrm{Fe}_{2} \mathrm{~B}\right)$ слоев:

1. $70 \% \mathrm{Na}_{2} \mathrm{~B}_{4} 0_{7}+30 \% \mathrm{SiC}$;

2. $70 \% \mathrm{Na}_{2} \mathrm{~B}_{4} 0_{7}+30 \% \mathrm{CMH} 17$.

Наиболее рационально применение данного способа борирования в мелкосерийном и серийном производствах [16-19]. 
К диффузионным методам нанесения покрытий относится насыщение из газовой paзы циркуляционным методом. Порошковая смесь в этом случае нагревается отдельно и за счет разложения газообразных соединений бора: диборана $\left(\mathrm{B}_{2} \mathrm{H}_{6}\right)$, треххлористого бора $\left(\mathrm{BCl}_{3}\right)$, трехбромистого бора $\left(\mathrm{BBr}_{3}\right)$, триметила $\left(\mathrm{CH}_{3}\right)_{3} \mathrm{~B}$ и других веществ, содержащих галогениды насыщающих элементов, подается в камеру с деталями. Этот способ позволяет увеличить температуру обработки с целью интенсификации процесса и решить вопрос насыщения покрытий на труднодоступные места деталей, например внутренние полости. Насыщение проводят при температурах $(800-850){ }^{\circ} \mathrm{C}$. Время выдержки варьируется от 2 до 6 ч. Существенное влияние на результаты борирования оказывает скорость газового потока. Для каждой установки она подбирается индивидуально. При рекомендованных режимах борирования на углеродистых сталях формируется слой боридов толщиной 50-200 мкм. К неконтактному методу нанесения покрытий относится насыщение в герметичной камере, когда порошок насыщающей смеси находится на дне под деталями. Такая камера позволяет проводить ХТО как в вакууме, так и в потоке любого инертного газа [20].

Среди методов получения покрытий интерес представляют газотермическое напыление и электронно-лучевое испарение. Из газотермических методов наиболее эффективным и универсальным можно считать плазменное напьление. Оно позволяет наносить практически любые высокотемпературные материалы, которые существенно не изменяют свой состав, и свойства под воздействием плазменной струи. Это дает возможность напылять покрытия заданного, контролируемого состава, что весьма важно при выборе рациональных систем защиты [21].

При электронно-лучевом способе нанесения покрытий специальный сплав испаряется в вакууме за счет энергии электронного пучка и затем осаждается на поверхность детали [22]. Достоинством метода является возможность осаждения практически любого сплава или соединения, что широко используется в практике создания высокотемпературных покрытий, особенно в случае опасности развития высокотемпературной коррозии. Необходимость сложного и дорогостоящего оборудования сдерживает широкое внедрение электронно-лучевых покрытий. Однако по мере повышения рабочих характеристик эти покрытия становятся основными на первых ступенях газовых турбин различного назначения [23]. Следует отметить, что основу напыляемых покрытий составляет металлическая матрица в виде твердых растворов на основе $\mathrm{Fe}, \mathrm{Ni}, \mathrm{Co}$, в которой расположены частицы боридов хрома, титана, молибдена, ниобия.

В последние годы активно разрабатываются новые методы борирования, в которых с целью интенсификации процесса насыщения используются различные источники концентрированной энергии: токи высокой частоты, тлеющий разряд, лазерное излучение, энергия электронных или ионных пучков [24]. В настоящее время не существует метода борирования, который бы по своим технико-экономическим показателям значительно превосходил все остальные. Каждый из методов имеет достоинства и недостатки. Выбор метода должен проводиться с учетом характера обрабатываемых изделий, условий их работы, массовости изготовления и экономичности.

\section{3. Влияние химического состава стали-основы на строение боридных покрытий}

При насыщении в различных борсодержащих средах в зависимости от условий насыщения образуются боридные слои, сильно различающиеся по своему строению. На структуру боридного покрытия влияет фазовый состав стали, на которую нанесено покрытие, а также ряд других факторов (активность насыщающей среды, способ борирования, температура процесса).

Диффузия бора в поверхность стали приводит к образованию слоя с зазубренной границей, связанного с основным металлом или переходной зоной. На рис. 1 а представлен 
схематический разрез двухфазного борированного слоя на поверхности углеродистой стали. Богатый бором темный слой $\mathrm{FeB}$ лежит у внешней границы, а ниже его расположена обедненная бором более светлая фаза $\mathrm{Fe}_{2} \mathrm{~B}$. Затем идет диффузионная зона, в которой концентрация бора плавно уменьшается от 5 мас. \% до его содержания в стали-основе. Обычно за толщину слоя принимают максимальную длину игл [25].

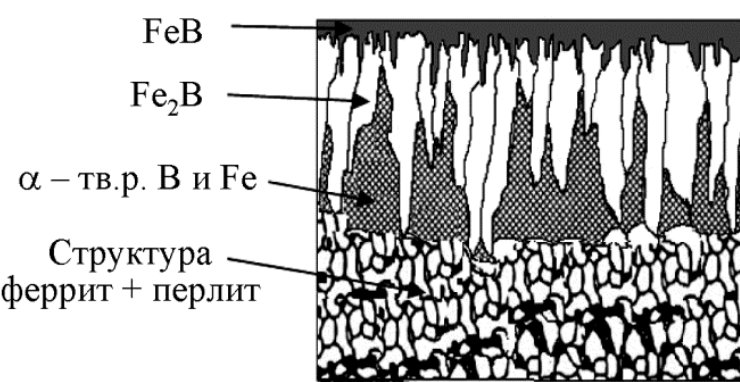

$a$

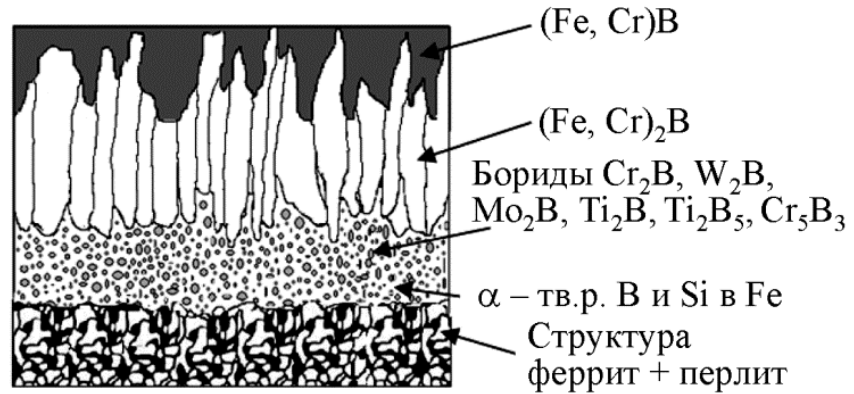

$\sigma$

Рис. 1. Схематическая структура двухфазного боридного слоя: $a-$ на углеродистой стали Ст $3 ; \sigma$ - на штамповой стали 4Х5МФС

В соответствии с основными принципами диффузии углерод в процессе борирования оттесняется от поверхности стали и в насыщаемой зоне образуется зона сплошных боридов, химический состав, форма и структура которых напрямую зависит от химического состава стали. Углерод, вытесненный из поверхностного слоя, образует собственную зону повышенной концентрации, которая располагается непосредственно за слоем боридов. По ширине такая зона оказывается значительно шире боридной, и ее размеры определяются наличием или отсутствием в стали карбидообразующих элементов. Карбидообразующие элементы, резко снижая скорость диффузии углерода, уменьшают ширину слоя [26, 27]. Такие легирующие элементы стали, как ванадий, вольфрам, молибден, титан, никель, кремний, ограничивают рост борированного слоя и снижают его зазубренность (рис. 1 б) [28]. Боридное покрытие имеет практически плоскую границу при высоком содержании вышеперечисленных элементов в стали, что отрицательно влияет на связь слоя боридов с основным металлом.

Структура, глубина и состав переходной зоны определяют, в частности, характер распределения остаточных напряжений, прочность связи боридного слоя с основным металлом, склонность его к хрупкому разрушению, условия образования и развития усталостных трещин, возможность продавливания слоя и другие параметры, поэтому при выборе стали и режима борирования необходимо учитывать особенности формирования структуры переходной зоны [29].

Влияние температуры и времени насыщения на толщину боридного покрытия на среднеуглеродистой стали представлено на рис. 2 и 3. Из приведенных данных следует, что с повышением температуры скорость нарастания толщины борированного слоя заметно увеличивается. Рост глубины борирования как функция температуры подчиняется экспоненциальной зависимости. При увеличении времени выдержки при борировании наиболее быстрый рост слоя боридов наблюдается впервые часы насыщения. С течением времени скорость нарастания толщины покрытия уменьшается и начиная с 24 ч глубина слоя практически не увеличивается. 


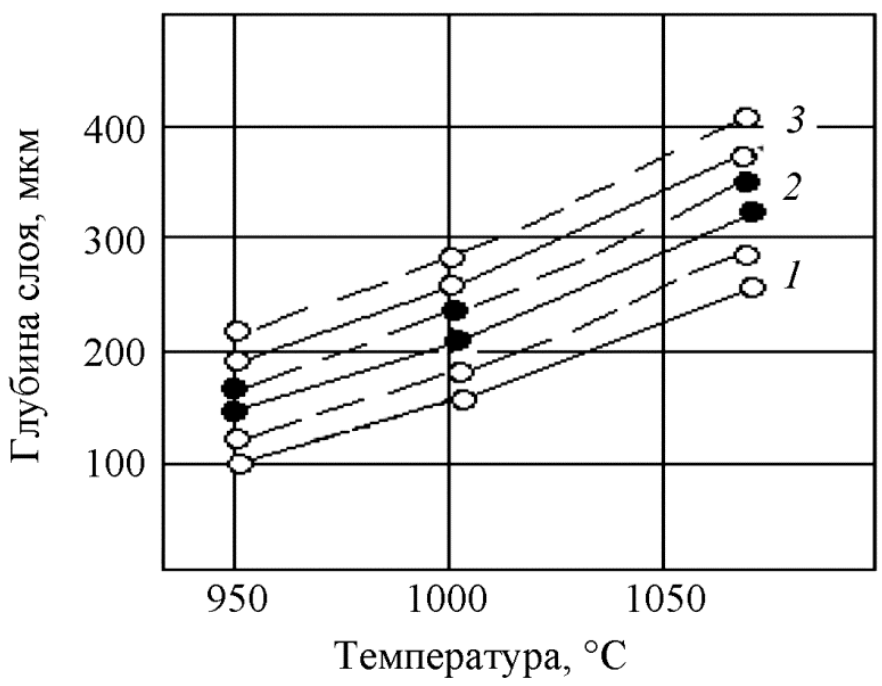

Рис. 2. Влияние температуры насыщения на глубину борированного слоя (сталь 40) [30]. Борирование из порошка карбида бора: 1, 2, 3- насыщение в течение 3, 5 и 8 ч соответственно

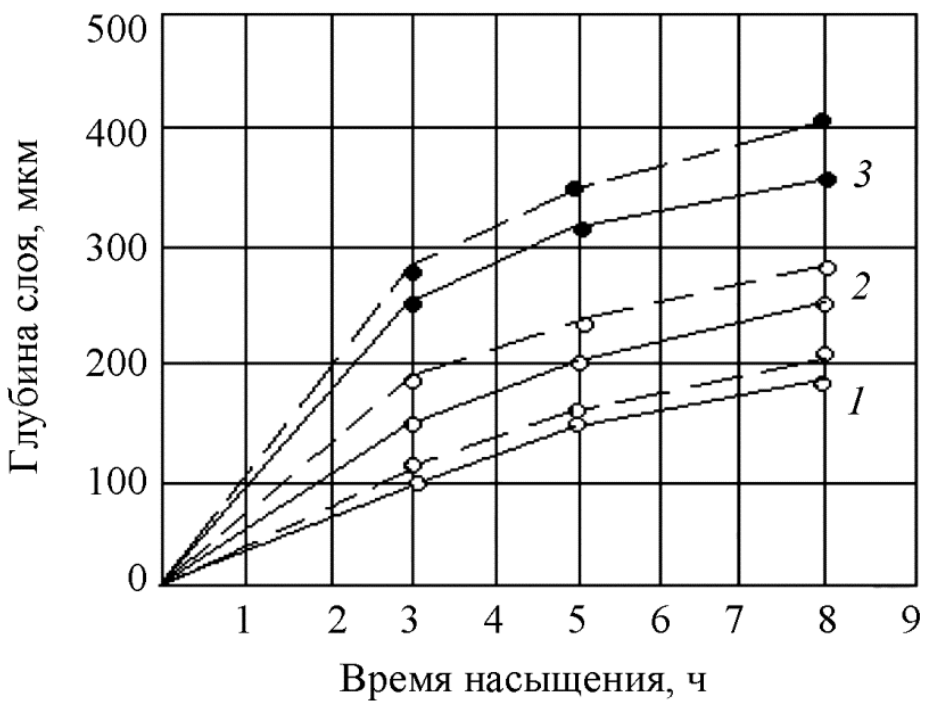

Рис. 3. Влияние времени насыщения из порошка карбида бора на глубину борированного слоя [31]: 1 - при $950{ }^{\circ} \mathrm{C} ; 2$ - при $1000{ }^{\circ} \mathrm{C} ; 3$ - при $1070{ }^{\circ} \mathrm{C}$

Влияние легирующих элементов на глубину борированного слоя на среднеуглеродистой стали представлено на рис. 4. Из приведенных данных видно, что максимальное уменьшение глубины слоя наблюдается в сталях с молибденом и вольфрамом. Минимальное снижение глубины слоя дают никель и марганец. Хром и алюминий занимают промежуточное положение.

В работе [33] детально исследованы структура и характер распределения бора, железа и легирующих элементов по толщине полученных покрытий при насыщении из порошков карбида бора при температуре $900{ }^{\circ} \mathrm{C}$ в течение 6 ч на углеродистой (Ст3), штамповой (4Х5МФС) и легированной (12X18Н10Т) сталях (рис. 5). Явно выделяются три зоны покрытия: внешняя (1), соответствующая бориду $\mathrm{FeB}$, под ней зона (2), соответствующая бориду $\mathrm{Fe}_{2} \mathrm{~B}$, и зона (3) на границе со сталью-основой, соответствующая твердому раствору бора в феррите с плавным уменьшением содержания бора. 


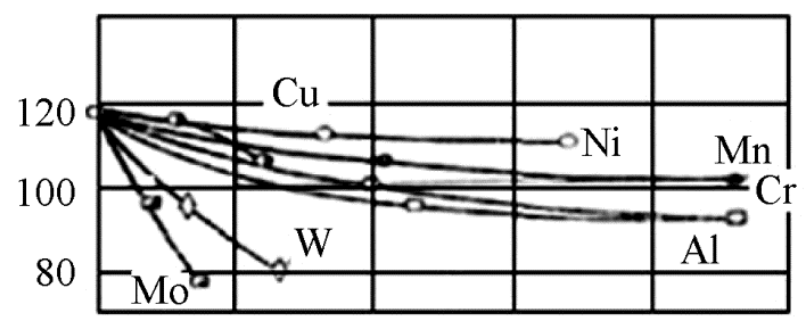

$a$

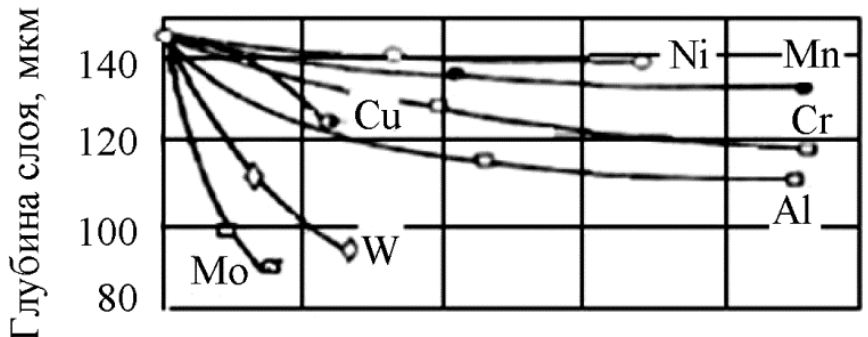

$\sigma$

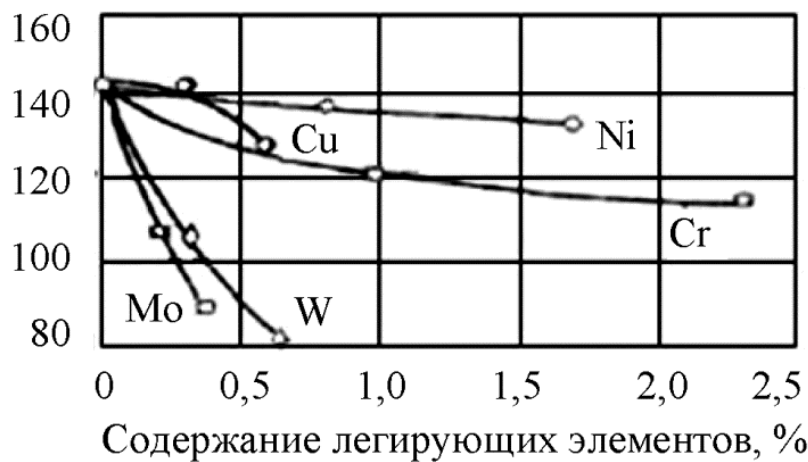

$B$

Рис. 4. Влияние легирующих элементов на глубину борированного слоя среднеуглеродистой стали $\left(0,40 \%\right.$ C) $\left(t=900{ }^{\circ} \mathrm{C}, 6\right.$ ч) [32]. Насыщение: $a$ - из порошка ферроборала; $\sigma$ - из порошка ферроборала 1-3\% хлористого аммония; 8 - из порошка карбида бора 4-3 \% хлористого аммония

На углеродистой стали марки Ст3 (рис. 5 a) покрытие представляет собой вытянутые зерна борида $\mathrm{FeB}$, основу покрытия составляет борид $\mathrm{Fe}_{2} \mathrm{~B}$; на границе со сталью образуется переходная зона твердого раствора бора в феррите (концентрация бора плавно уменьшается от 4 мас. \% до нуля в стали-основе). На штамповой стали (4Х5МФС) боридные иглы фазы $\mathrm{Fe}_{2} \mathrm{~B}$ скругляются (рис. 5 б). Фазы $\mathrm{FeB}$ и $\mathrm{Fe}_{2} \mathrm{~B}$ содержат хром в количествах, близких его содержанию в стали-основе, т. е. по сути являются легированными боридами $(\mathrm{Fe}, \mathrm{Cr}) \mathrm{B}$ и $(\mathrm{Fe}, \mathrm{Cr})_{2} \mathrm{~B}$. Переходная зона представляет механическую смесь борированного феррита, в котором содержание бора плавно убывает до нуля, и глобулярных частиц боридов хрома, вольфрама, молибдена и титана. На легированной стали (12X18Н10Т) покрытие не имеет выраженного игольчатого строения (рис. 5 в), как на углеродистой или штамповой сталях. На границах аустенитного зерна под покрытием наблюдаются мелкие бориды хрома. 


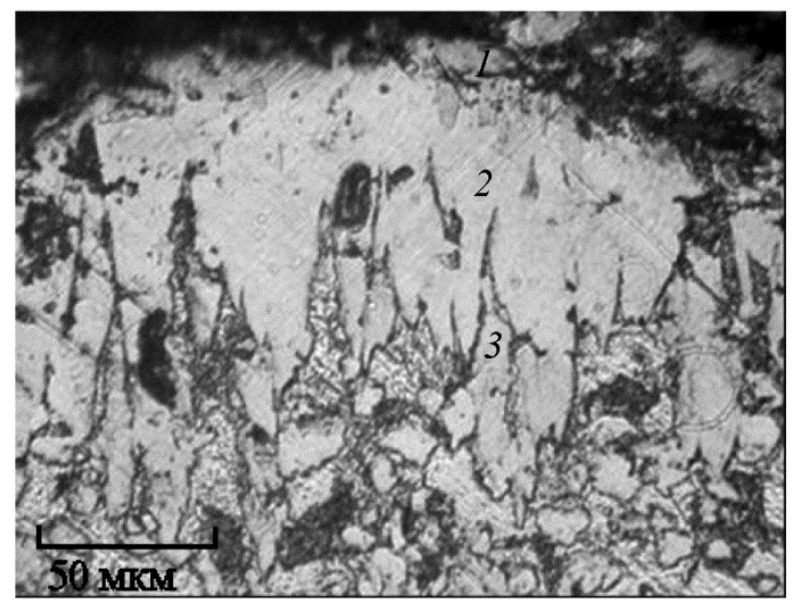

$a$
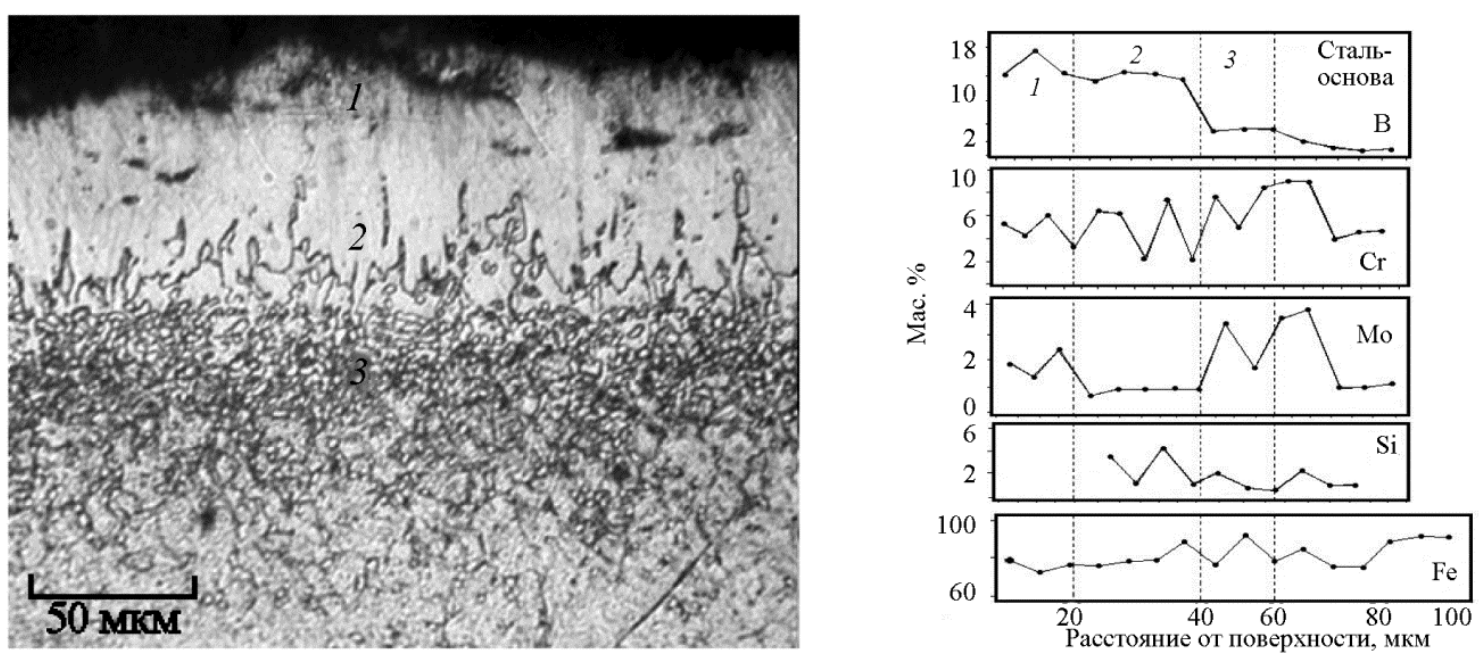

$\sigma$
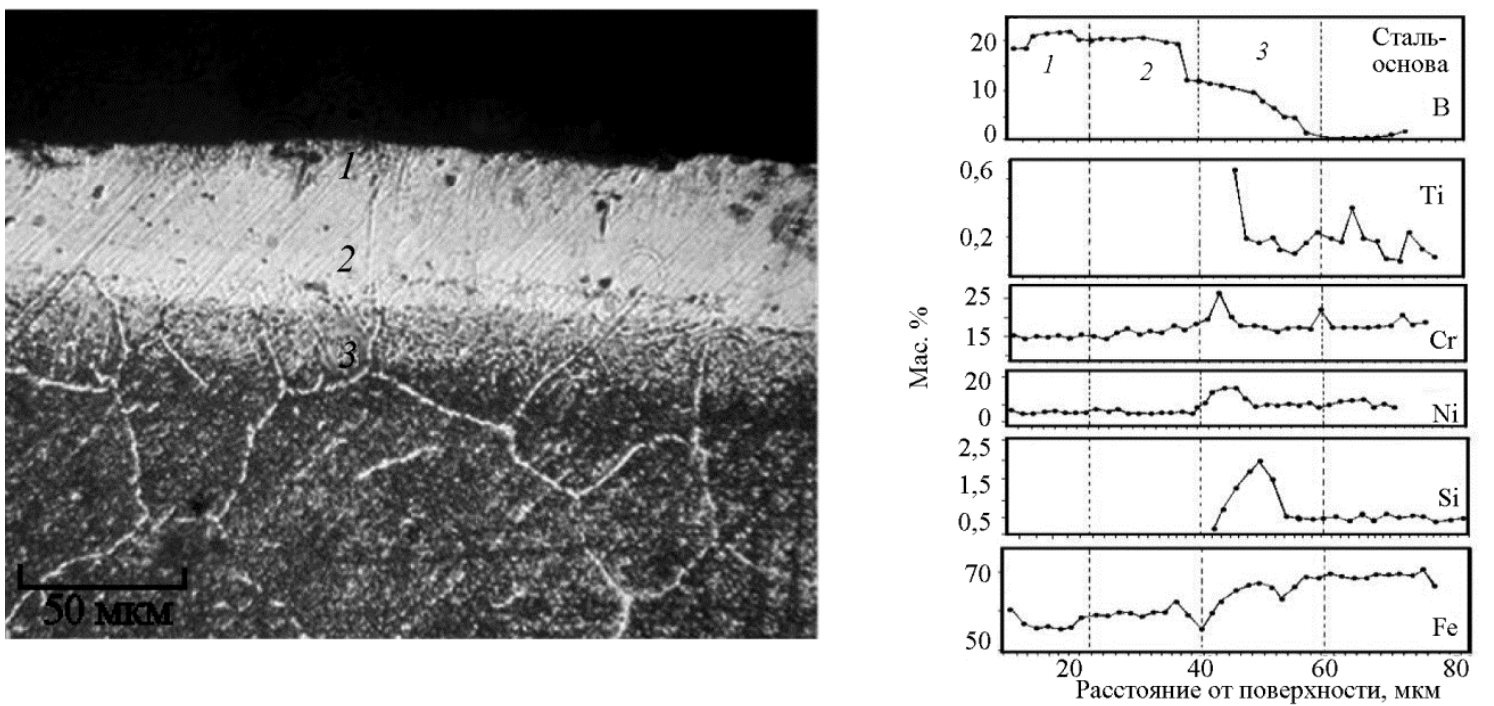

B

Рис. 5. Микроструктура боридных покрытий, полученных в порошковой смеси:

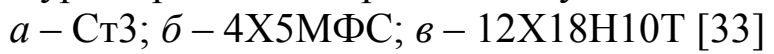


Следует отметить, что содержание бора в виде твердого раствора в феррите (или аустените на стали $12 \mathrm{X} 18 \mathrm{H} 10 \mathrm{~T})$ в переходной зоне на легированных сталях заметно меньше, чем на углеродистой стали марки Ст3. Это связано с оттеснением легирующих элементов на границу «покрытие - сталь» и соединением их с бором, сосредоточенным в переходной зоне с образованием глобулярных дисперсных частиц боридов. При этом твердый раствор вокруг этих частиц обедняется по бору. Кремний, как и углерод, не растворяется в боридах железа и практически весь оттесняется в переходную зону под слой фазы $\mathrm{M}_{2} \mathrm{~B}$. Причем, если углерод как элемент внедрения довольно быстро проникает вглубь стали, то кремний как элемент замещения перемещается довольно медленно при температуре насыщения и тормозит фронт развития боридной фазы. Вытесненный кремний сосредоточивается между кристаллами $\mathrm{M}_{2} \mathrm{~B}$, где резко повышается его концентрация: на стали 4Х5МФС при среднем содержании кремния в основе на уровне $\sim 0,8$ мас. \% после борирования концентрация этого элемента в довольно узком - толщиной (20-25) мкм - подслое на границе с покрытием может достигать 3,5 мас. \%. Микротвердость зоны кремнистого феррита немного ниже, чем твердость стали-основы. Образование относительно мягкой прослойки кремнистого феррита на границе «покрытие - основа» может играть роль своеобразного демпфера, тормозящего возникновение и рост усталостных трещин при больших контактных нагрузках, характерных для штампов горячего деформирования.

Никель при борировании стали $12 \mathrm{X} 18 \mathrm{H} 10 \mathrm{~T}$, также как и кремний в штамповых сталях, оттесняется при диффузионном борировании в переходную зону на границе «покрытие-сталь», где его концентрация достигает 13 мас. \%. Однако никель входит и в состав боридов в покрытии в количествах от 3 до 5 мас. \%. Следует отметить, что при борировании стали $12 \mathrm{X} 18 \mathrm{H} 10 \mathrm{~T}$ легирующие элементы в максимальной степени оказывают тормозящее действие на процесс формирования покрытия. Это проявляется не только в заметном уменьшении толщины борированного слоя, но и максимально высоких значениях концентрации бора в покрытии и, как следствие, увеличении количества борида МВ и более высоких значениях микротвердости, а также в изменении структуры покрытия. Процентное содержание борида FeB на сталях приведено в табл. 1. [34]

Таблица 1 - Изменение количества борида МВ в сталях разного химического состава [35]

\begin{tabular}{|l|c|}
\hline \multicolumn{1}{|c|}{ Марка стали } & Об. \% MB \\
\hline Ст3 & 18 \\
\hline 4X5МФС & 50 \\
\hline 12X18Н10T & 70 \\
\hline
\end{tabular}

Таким образом, проанализированные экспериментальные данные позволяют утверждать, что диффузионные боридные покрытия на сталях формируют градиентную гетерофазную композицию, состав и строение которой определяется химическим составом основы.

\section{4. Защитные свойства боридных покрытий}

Основными характеристиками высокотемпературных защитных покрытий, определяющими их эксплуатационные свойства, являются высокая твердость, износостойкость и термостойкость. При борировании в порошке ферроборала основной структурной составляющей слоя является $\alpha$-твердый раствор, поэтому твердость такого слоя невысока и равна 400-500 HV 0,1. Отмечается, что легирующие элементы (никель, хром, молибден) увеличивают твердость борированного слоя, причем сильнее всех действует хром $[35,36]$. 
Из табл. 2 следует, что изменение времени насыщения с 3 до 8 ч не меняет высокой твердости слоя, она во всех случаях равна 1440-1450 HV 0,1, а с температуры 1100 до $1200{ }^{\circ} \mathrm{C}$ в слое наблюдается эвтектика, что приводит к резкому уменьшению твердости до $760 \mathrm{HV} 0,1$.

Таблица 2 - Микротвердость фаз борированного слоя стали 40 [36]

\begin{tabular}{|c|c|c|c|}
\hline \multicolumn{2}{|c|}{ Условия насыщения } & \multirow{2}{*}{$\begin{array}{l}\text { Структурные } \\
\text { составляющие }\end{array}$} & \multirow{2}{*}{$\begin{array}{c}\text { Микротвердость, } \\
\text { HV } 0,1\end{array}$} \\
\hline Температура, ${ }^{\circ} \mathrm{C}$ & Время, ч & & \\
\hline 950 & 8 & \multirow{4}{*}{$\mathrm{Fe}_{2} \mathrm{~B}$} & 1440 \\
\hline 1000 & 3 & & 1450 \\
\hline 1000 & 5 & & 1450 \\
\hline 1000 & 8 & & 1440 \\
\hline 1100 & 3 & \multirow{4}{*}{ Эвтектика } & 840 \\
\hline 1100 & 8 & & 860 \\
\hline 1200 & 5 & & 760 \\
\hline 1200 & 8 & & 760 \\
\hline
\end{tabular}

На основании указанных исследований отмечается, что в сталях, легированных титаном и ванадием при $1000{ }^{\circ} \mathrm{C}$, твердость борированного слоя равняется $1430 \mathrm{HV} \mathrm{0,1.}$ Такая же твердость получается и на армко-железе. В углеродистой стали твердость несколько ниже (1230-1260 HV 0,1) и достигается уже при $1000{ }^{\circ} \mathrm{C}$. Дальнейшее повышение температуры не приводит к увеличению твердости [36].

Твердость борированного слоя хромистых и медьсодержащих сталей практически не отличалась от твердости слоя, полученного на углеродистой стали. Минимальную твердость имели слои на никелевых сталях (850 HV 0,1), а максимальную твердость на нержавеющей стали. Закалка с повторного нагрева после борирования практически не сказывается на твердости слоя [37].

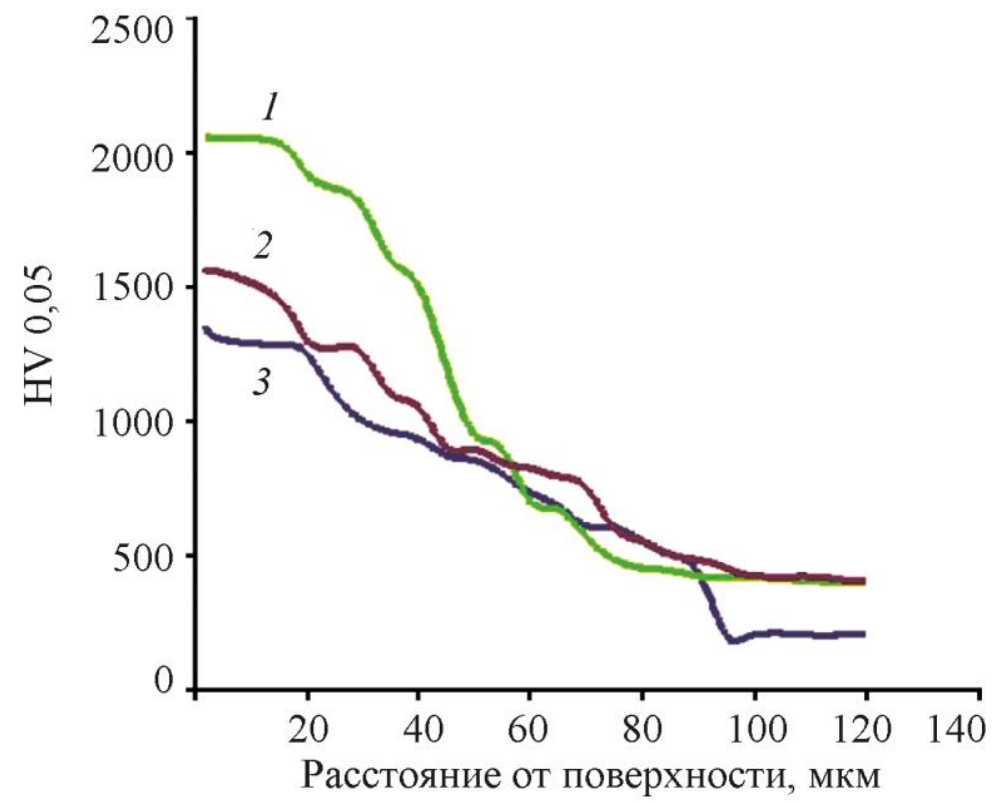

Рис. 6. Характер распределения значений микротвердости по толщине боридных покрытия на сталях разных марок: 1 - сталь 12Х18Н10Т; 2 - сталь 4Х5МФС; 3 - сталь Ст 3 
Характер распределения значений микротвердости совпадает с распределением бора по толщине покрытий (рис. 6). Хорошо различимы три зоны покрытия: внешняя - с максимальной твердостью, соответствующая бориду $\mathrm{FeB}$, вторая - $\mathrm{Fe}_{2} \mathrm{~B}$ и переходная на границе с основой, соответствующая твердому раствору бора в феррите. Разные значения твердости обусловлены разным соотношением количества боридов $\mathrm{MB}$ и $\mathrm{M}_{2} \mathrm{~B}$ в покрытиях на сталях разных систем легирования (табл. 2).

Высокую степень твердости обычно отождествляют с повышенным сопротивлением износу. Однако кроме твердости существуют другие параметры, определяющие сопротивление износу: чистота поверхности, преимущество холодной сварки, а также характер нагрузки. Два параметра слоя боридов благоприятны для сопротивления износу: это высокая твердость, 1700-2500 HV 0,05 и минимальная склонность к адгезионному схватыванию.

Боридные покрытия, обладая стабильным и низким коэффициентом трения [37], имеют хорошие антифрикционные свойства, что обеспечивает надежную защиту поверхности материала от разрушения. Следует заметить, что износ боридного покрытия происходит послойно, а неизменный по толщине химический состав образовавшихся при насыщении упрочняющих фаз $\left(\mathrm{Fe}_{2} \mathrm{~B}\right.$ или $\left.\mathrm{FeB}+\mathrm{Fe}_{2} \mathrm{~B}\right)$ стабилизирует скорость изнашивания на определенном уровне вплоть до полного исчезновения защитного слоя. В результате защитные свойства будут во многом определяться толщиной покрытия, которая должна быть максимально возможной при условии сохранения механических характеристик обрабатываемой стали $[28,30]$.

Испытания на износ при нагрузке 490 Н для боридного покрытия на Ст3 и 1274 $\mathrm{H}$ для стали 4Х5МФС показали, что происходит фрагментация боридов $\mathrm{Fe}_{2} \mathrm{~B}$ на Ст3 (рис. 7 a), существенная пластическая деформация боридов $(\mathrm{Fe}, \mathrm{Cr})_{2} \mathrm{~B}$, проявившаяся в формоизменении зерен боридов для стали 4Х5МФС (рис. 7 б), поверхностный слой окисляется с образованием преимущественно оксида $\mathrm{FeO}$ и некоторого количества оксида $\mathrm{Fe}_{2} \mathrm{O}_{3}$ [38-40].

Большое влияние на сопротивление износу оказывает модифицирование боридного покрытия такими элементами, как алюминий и магний. Особенно заметно это проявляется при больших скоростях скольжения, когда сопротивление износу определяется окислительными реакциями и формированием на контактных поверхностях соответствующих окислов. Введение в защитный слой элементов, образующих плотные, бездефектные окислы (б- $\mathrm{Al}_{2} \mathrm{O}_{3}$ и $\left.\mathrm{MgO}\right)$, оказалось весьма полезным и обеспечило повышение износостойкости обычных боридных покрытий. Если для горячей штамповки этот эффект вряд ли будет заметен, то для машин литья под давлением, где скорости относительного проскальзывания в пресс-формах значительно выше, модифицированные боридные покрытия должны быть более предпочтительны [41].

Исследования упрочненного слоя [42] на характер растрескивания боридных покрытий в условиях активного нагружения показали, что развитие пластической деформации в борированных образцах в значительной мере определяется толщиной покрытия. Характерной особенностью кривых растяжения является наличие площадки текучести при толщине боридного слоя менее 100 мкм и ее отсутствие в образцах с большей толщиной покрытия. На рис. 8 приведены зависимости, иллюстрирующие изменения механических характеристик поверхностно упрочненных образцов с увеличением толщины боридного слоя. 


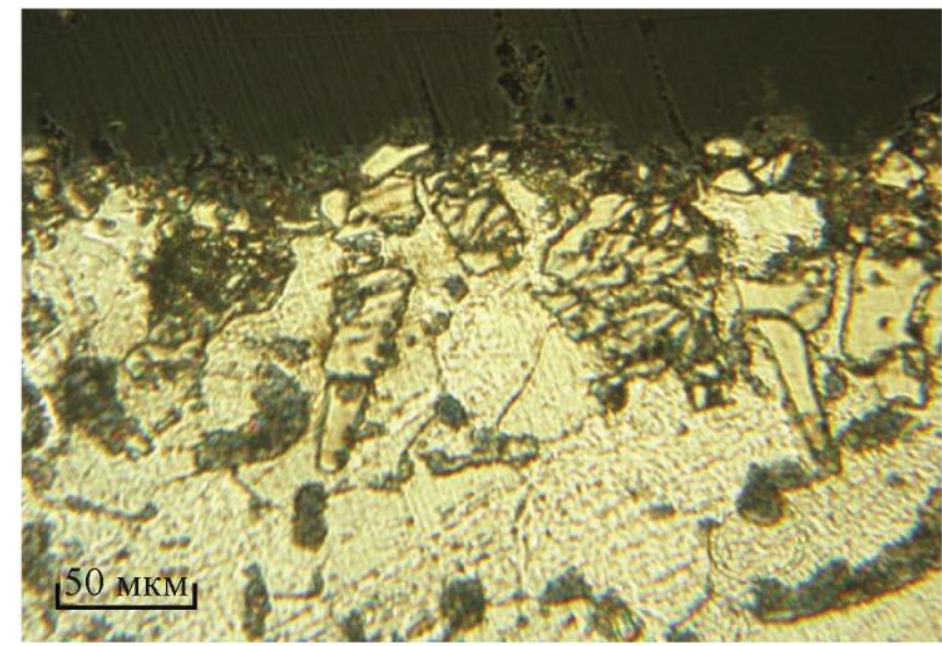

$a$

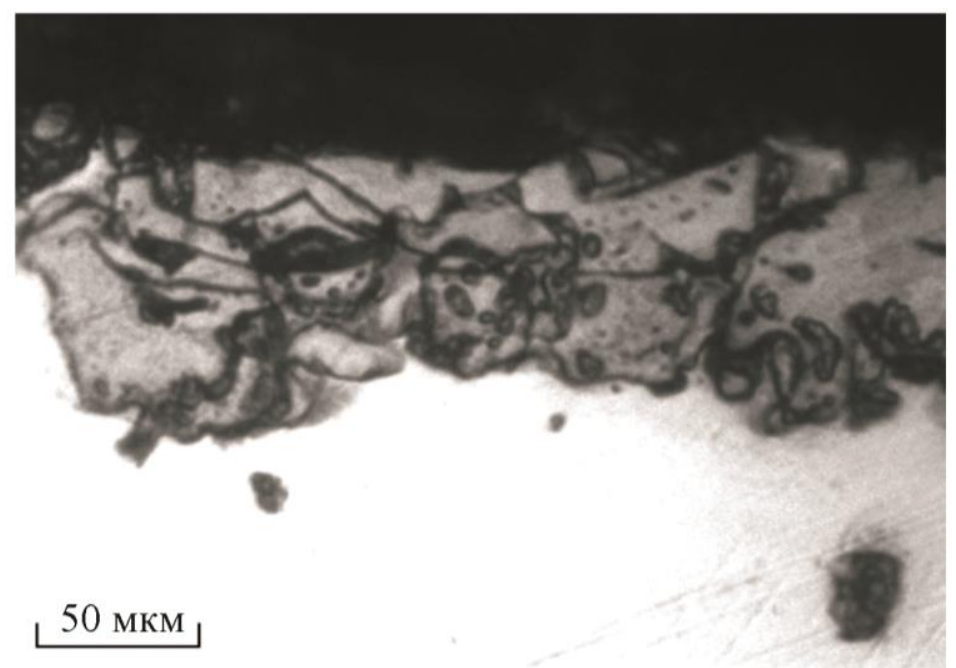

6

Рис. 7. Изменение строения боридного покрытия после трибологического воздействия: $a$ - на стали Ст3 после испытаний при нагрузке $490 \mathrm{H}$; $\sigma$ - на стали 4 Х5МФС с закалкой при нагрузке 1274 H [37]

Одной из важных характеристик боридных покрытий является термостойкость. Термостойкость - это стойкость покрытий к растрескиванию при смене температур. Она оценивалась по результатам испытаний на термоциклирование $[4,44,45]$. Растрескивание боридного слоя начинается после достижения уровня напряжений, соответствующего пределу текучести композиции. При этом растрескивание можно разделить на первичное и вторичное. Первичное растрескивание покрытия наблюдалось на начальных этапах пластического течения, в то время как вторичное растрескивание имело место при значительных степенях деформации. Признаками, по которым помимо степени деформации разделяли первичное и вторичное растрескивание, являются расположение (ориентация относительно направления приложенной нагрузки), длина и визуально определяемая глубина трещин. 


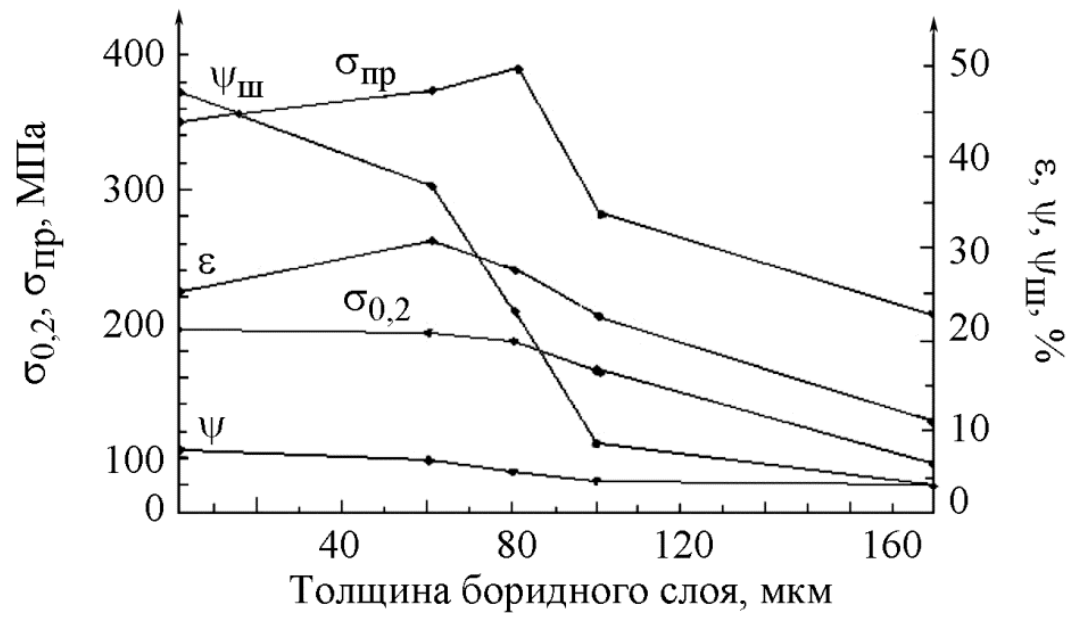

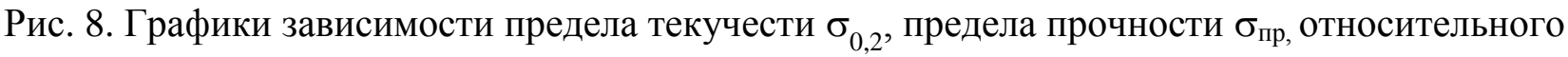
удлинения $\varepsilon$, относительного сужения $\psi$ и относительного сужения в шейке $\psi_{ш}$ исследованных образцов от толщины $\delta$ боридного слоя [43]

Химический состав стали-основы оказывает заметное влияние на характер повреждения боридных покрытий при термоциклировании. При термоциклировании образцов из углеродистой стали (Ст3) с покрытием первоначально происходят локальные повреждения. В окислительной атмосфере (воздух, азот) это выражается в точечном «вспучивании» покрытия, на поверхности появляются «пузыри», размеры которых увеличиваются с ростом максимальной температуры цикла и количества циклов (рис. 9). Известно $[3,4]$, что бориды обладают достаточно высокой стойкостью к окислению. Однако проникновение кислорода на границу с основой может происходить достаточно быстро по линейным межзеренным границам боридных игл, расположенным перпендикулярно поверхности. Здесь кислород активно окисляет сталь-основу, происходит образование оксидов железа $\mathrm{FeO}$ и $\mathrm{Fe}_{2} \mathrm{O}_{3}$, которые выталкивают наружный борированный слой.

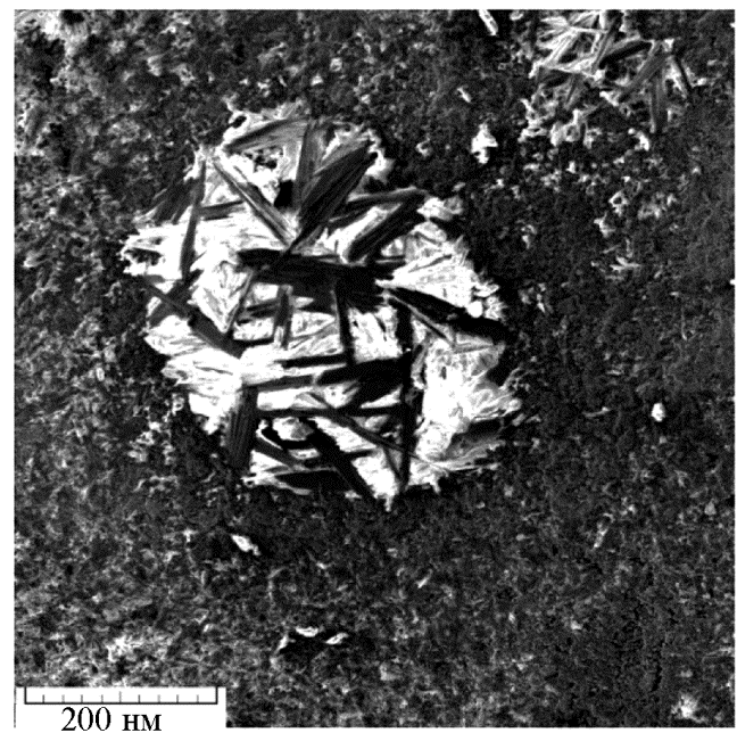

Рис. 9. Характер разрушения диффузионного боридного покрытия при термоциклировании $1000{ }^{\circ} \mathrm{C}$ на воздухе на Ст3 [4]

При проведении испытаний в воздушной атмосфере происходит интенсивное окисление стали под покрытием, вызывающее повреждение борированного слоя по всему пери- 
метру поверхности. В момент разрушения образца довольно толстый слой окислов вместе с покрытием отшелушивается от поверхности, за счет чего диаметр образца в месте разрыва уменьшается на 1-1,5 мм.

При термоциклировании образцов штамповой стали (4Х5МФС) с боридным покрытием (толщиной 100 мкм) первичное растрескивание покрытия начинается вблизи галтельных переходов «головка - рабочая часть образца» и распространяется последовательно от галтельных переходов в направлении центра образца (рис. 10) $[44,46]$.

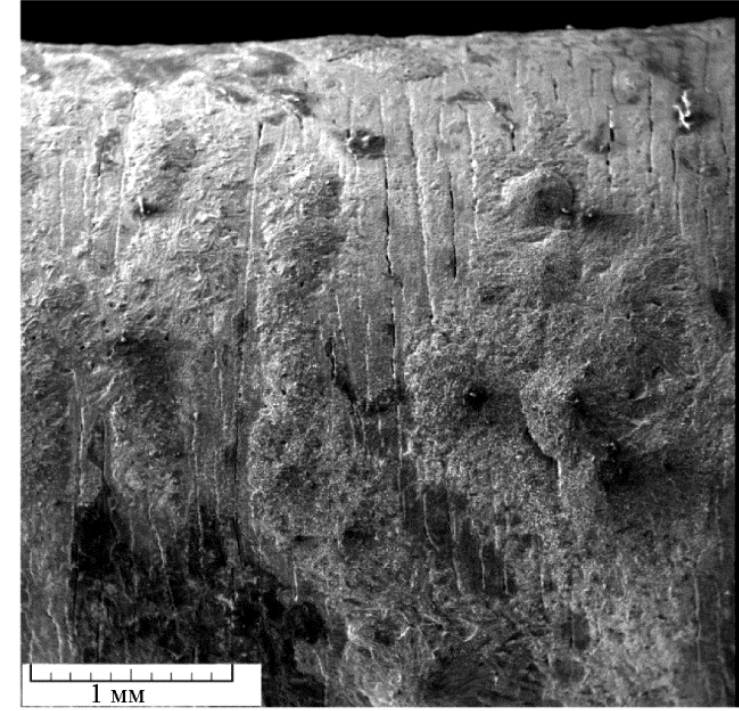

$a$

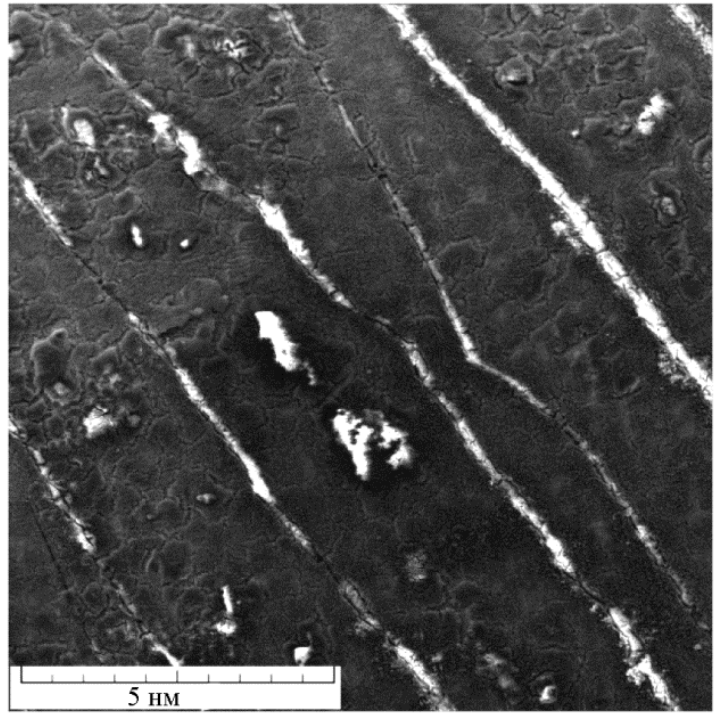

$\sigma$

Рис. 10. Изображение разрушенных образцов с боридным покрытием на стали 4Х5МФС с образованием первичных трещин: $a$ - возле головки образца; $\sigma$ - центральная часть

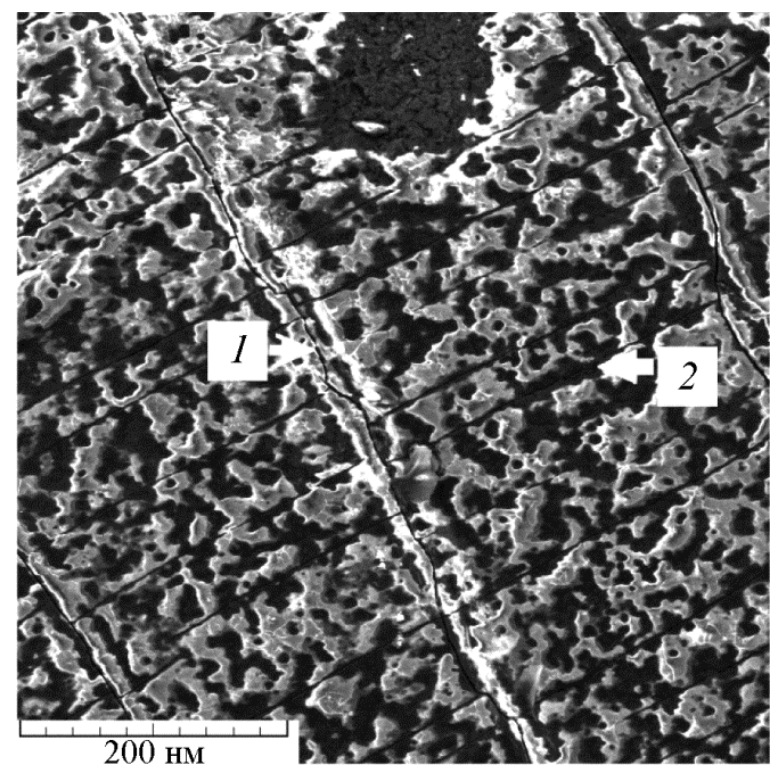

Рис. 11. Изображения первичных (1) и вторичных (2) трещин в боридном покрытии на стали 4Х5МФС [35]

По мере увеличения степени деформации начинается вторичное растрескивание боридного слоя, в ходе которого происходит разбиение первичных фрагментов покрытия 
на более мелкие. Вторичные трещины являются поперечными и расположены параллельно первичным трещинам (рис. 11).

Вторичные трещины являются более тонкими и не всегда распространяются через всю ширину покрытия. Причиной вторичного растрескивания в образцах с тонкими покрытиями авторы [45] считают действие на покрытие локальных сжимающих напряжений, возникающих в результате формоизменения основы, претерпевающей впоследствии малого модуля упругости большие поперечные деформации. На границе раздела возникают мощные разориентированные поворотные моменты, приводящие к разворотам, а также происходит экструдирование фрагментов боридного слоя. Таким образом, ориентация вторичных трещин в тонких покрытиях преимущественно перпендикулярна направлению действия сжимающих напряжений.

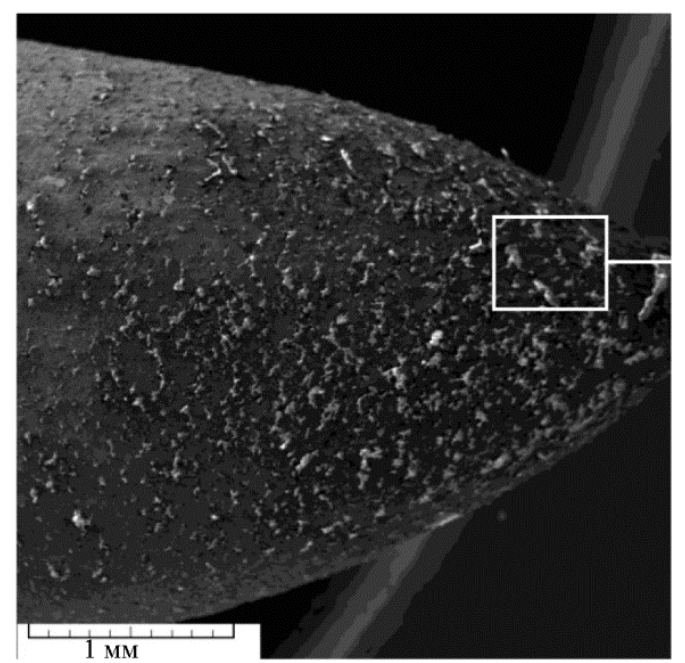

$a$

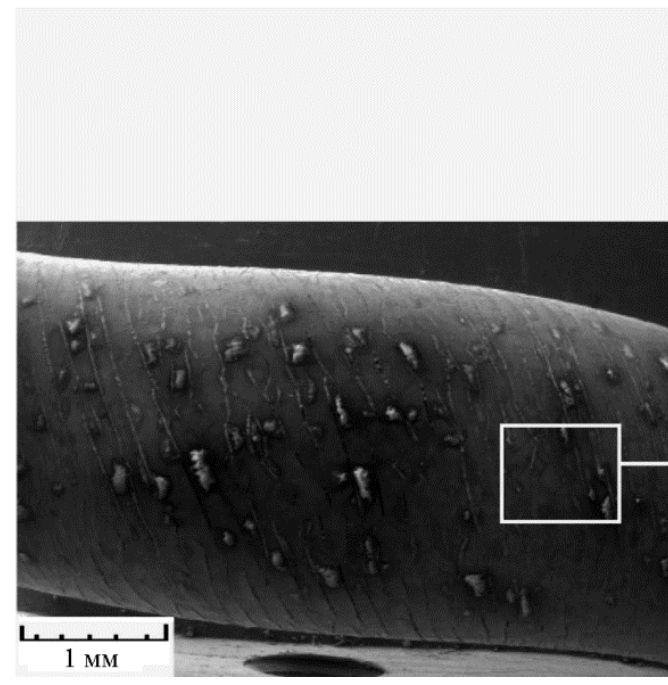

B

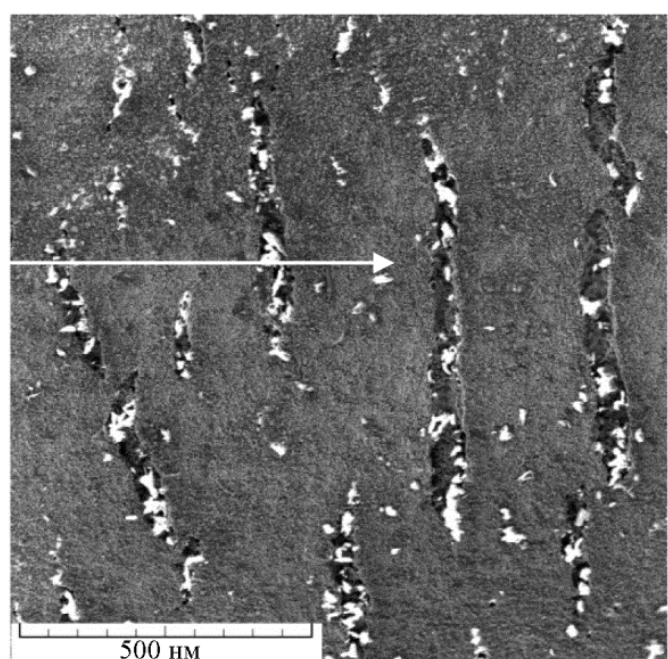

$\sigma$

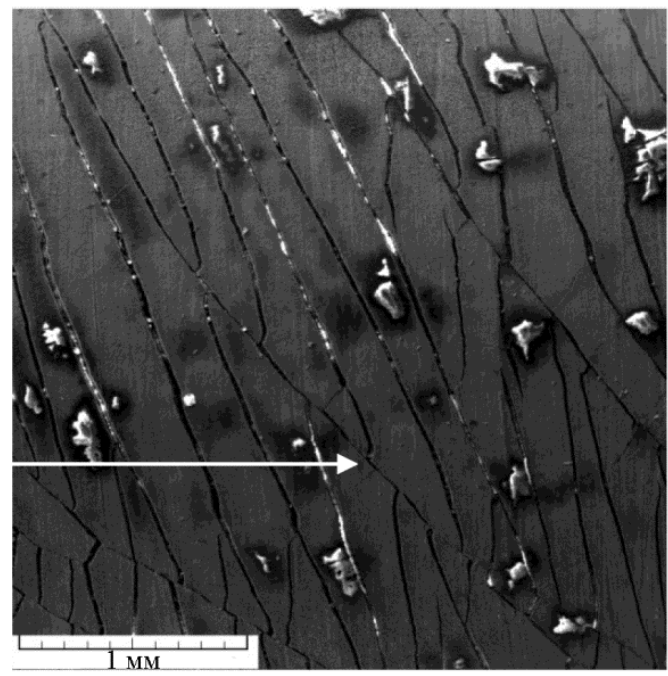

2

Рис. 12. Рельеф поверхности после термоциклирования при $1000^{\circ} \mathrm{C}$ в водороде: $a, \sigma$ - на Ст3; в, г - на стали 4Х5МФС [35]

В восстановительной атмосфере водорода исключено образование оксидов железа, поэтому «вспучивания» покрытия не обнаружено. Первые локальные повреждения покрытия выражаются в растрескивании слоя боридов. На Ст3 разрушение покрытия происходит путем квазипериодического прерывистого растрескивания, переходящего в стохастически 
разветвленное при больших степенях деформации в области шейки (рис. $12 a$, б). При этом его диаметр в области разрушения уменьшился от 5 до 0,65 мм (рис. $12 a$ ), т. е. относительное сужение составило около 98 \% [4]. Пластическая деформация образца произошла за счет стали-основы на участках растрескивания покрытия: на поверхности наблюдаются сохранившиеся «островки» покрытия с полосами деформации стали-основы между ними (рис. 12 б). По мере приближения к области разрушения, т. е. при увеличении степени пластической деформации образца и действующих растягивающих напряжений, увеличивается площадь поверхности, занятая деформированной сталью без покрытия, и уменьшается доля поверхности, занятая сохранившимся покрытием.

На стали 4Х5МФС растрескивание боридного слоя характеризуется формированием нескольких магистральных трещин. Игольчатая структура покрытия обусловливает возникновение значительного количества небольших по мощности мезоконцентраторов напряжений, поэтому покрытие растрескивается достаточно мелко. Разрушение покрытия носит характер квазипериодического растрескивания с образованием сплошных трещин по диаметру и вдоль образца, пластическая деформация составила всего 21 \% (рис. 12 в, г).

Таким образом, разрушение борированного слоя при термоциклировании во многом определяется окислительными процессами, происходящими на поверхности. С этой точки зрения долговечность покрытия на сталях, содержащих не менее 5 мас. \% хрома, существенно выше за счет образования защитного окисла $\mathrm{Cr}_{2} \mathrm{O}_{3}$.

Испытания на удар (начальная высота падающего бойка 250 мм) показали, что при комнатной температуре покрытие весьма хрупкое и в зоне деформации (диаметр кратера 1,59 мм) практически все скалывается вплоть до диффузионной зоны. Нагрев образца позволяет сохранить сплошность покрытия даже при значительно больших деформациях (диаметр кратера при 200 и $600{ }^{\circ} \mathrm{C}-1,86$ и 2,01 мм соответственно). В этом случае только в отдельных участках внешней зоны, где присутствует высокобористая фаза FеВ, наблюдаются отдельные сколы, но на глубину не более (20...30) \% от толщины всего слоя. Таким образом, боридные покрытия могут с успехом работать в условиях ударных нагрузок при повышенных рабочих температурах.

\section{5. Выводы}

Из анализа литературы по вопросам нанесения боридных следует, что в зависимости от формы и размеров инструмента необходимо выбирать соответствующие насыщающие составы: борирующие пасты на основе карбида бора либо порошковые смеси. Существенное влияние на защитные свойства диффузионных боридных покрытий оказывает химический состав стали-основы. Основной путь повышения долговечности и эксплуатационных свойств диффузионных покрытий заключается в рациональном легировании покрытий элементами, повышающими термическую стабильность защитного слоя и сопротивление изнашиванию. Наиболее перспективными легирующими элементами являются хром и кремний. Для легирования покрытий хромом и кремнием следует использовать возможность естественного легирования из стали-основы, что достигается соответствующей технологией нанесения покрытий, определяющей механизм их формирования.

При прогнозировании конструкционной прочности материалов и элементов конструкций необходимо учитывать, что деформация детали в целом определяется свойствами тонкого поверхностного слоя, а разрушение - механизмом образования и развития трещин как на поверхности, так и в основе. Поэтому весьма важную роль играет термодиффузионное насыщение, в том числе бором остается основным методом нанесения защитных покрытий. Правильно выбранные состав порошковой насыщающей смеси и режим ХТО с учетом химического состава защищаемого материала позволяют получать качественные, высокоэффективные диффузионные покрытия. 


\section{Благодарность}

Работа выполнена в соответствие с государственным заданием по теме № AAAAA18-118020790145-0.

\section{Список литературы}

1. Structural properties of boride coatings for triboengineering / S. Yu. Tarasov, G. V. Trusova, A. V. Kolubaev, and O. V. Sizova // Metal Science and Heat Treatment. - 1995. Vol. 37. - P. 257-260. - DOI: 10.1007/BF01152230.

2. Мальцева Л. А., Гервасьев М. А., Кутьин А. Б. Материаловедение. - Екатеринбург : Изд-во УГТУ-УПИ, 2007. - 338 с.

3. Гузанов Б. Н., Косицын С. В., Пугачева Н. Б. Упрочняющие защитные покрытия в машиностроении : монография. - Екатеринбург : Изд-во УрО РАН, 2003. - 242 с.

4. Особенности разрушения диффузионного боридного покрытия на углеродистой стали в условиях термоциклирования под нагрузкой / Н. Б. Пугачева, Л. М. Замараев, Е. Б. Трушина, Т. М. Гурченко // Упрочняющие технологии и покрытия. - 2011. - № 3. - С. 24-30.

5. Бурнышев И. Н., Валиахметова О. М., Мутагарова С. А. К вопросу борирования сталей // Вестник ИжГТУ им. М. Т. Калашникова. - 2007. - № 4. - С. 124-127.

6. Мозберг Р. К. Материаловедение. - М. : Высшая школа. - 1991. - 448 с.

7. Домбровский Ю. М., Степанов М. С. Новые аспекты химико-термической обработки металлов в порошковых средах. // Вестник Донского государственного технического университета. - 2011. - Т. 11, № 8-1 (59). - С. 1217-1221.

8. Анфиногенов А. И., Чебыкин В. В., Чернов Я. Б. Анализ развития химикотермической обработки металлов и сплавов // Расплавы. - 2005. - № 3. - С. 40-52.

9. Ворошнин Л. Г., Менделеева О. Л., Сметкин В. А. Теория и технология химикотермической обработки. - М. : Новое издание. - 2010. - 304 с.

10. Перспективные материалы. Структура и методы исследования : учебное пособие / под ред. Д. Л. Мерсона. - Тольятти : ТГУ; Москва : МИСиС, 2006. - 536 с.

11. Малькова Н. Ю. Недостатки процессов и перспективные способы химикотермической обработки // Успехи современного естествознания. - 2007. - № 12. - С. 106-107.

12. Особенности структуры и свойств боридных диффузионных слоев, оптимизация технологии их получения / В. Н. Гадалов, А. С. Борсяков, В. Г. Сальников, Б. Н. Квашнин, Л. А. Желанова // Известия Юго-Западного государственного университета. Серия «Техника и технологии». - 2012. - № 2 (1). - С. 73-77.

13. Ковенский И. М., Поветкин В. В. Металловедение покрытий. - М. : Интермет Инжиниринг. - 1999. - 296 с.

14. Борсяков А. С., Гадалов В. Н., Колмыков В. И. Электролизное борирование металлов и сплавов // Сварка и родственные технологии в машиностроении и электронике : региональный сборник научных трудов. - Курск, Курский государственный технический университет. - 2002. - С. 13-22.

15. Future development in plasma spray coating / A. R. Nicholl, H. Gruner, G. Wuest, S. Keller // Mater. Sci. Technol. - 1996. - Vol. 2, no. 3. - P. 214-219. - DOI: 10.1179/mst.1986.2.3.214.

16. Борирование низкоуглеродистой стали с использованием технологии вневакуумной электронно-лучевой обработки / А. М. Теплых, Е. Д. Головин, В. А. Батаев, М. Г. Голковский, А. А. Батаев, А. С. Гонтаренко, Е. А. Дробяз // Международная конференция по физической мезомеханике, компьютерному конструированию и разработке новых материалов, Томск, 5-9 сентября, 2011 г. - Томск : ИФПМ СО РАН, 2011. - С. 494-496.

17. Пугачева Н. Б., Быкова Т. М. Характер повреждений цементованных и борированных поверхностей на деталях режущей пары гидромеханического щелевого перфоратора // 
Обработка металлов (технология, оборудование, инструменты). - 2015. - № 1 (66). C. 51-59. - DOI: 10.17212/1994-6309-2015-1-51-59.

18. Бутуханов В. А., Мархасаева Ю. А., Мархасаев А. В. Диффузионное защитное покрытие после насыщения бором и ванадием на сталях для штампового инструмента // Электротехника. Энергетика. Машиностроение : сборник научных трудов I Международной научной конференции молодых ученых. - Новосибирск, 2014. - С. 195-198.

19. Шилякин Л. В., Веропаха Д. Н., Веропаха Н. В. Метод модификации жидкостным борированием стальных изделий с целью повышения их эксплуатационных свойств // Известия высших учебных заведений. Северо-Кавказский регион. Серия «Технические науки». - 2014. - № 1. - С. 48-51.

20. Упрочняющие и восстанавливающие покрытия / Г. С. Гун, В. В. Кривощапов, М. В. Чукин, В. С. Адамчук, А. М. Цун. - Челябинск : Металлургия, 1991. - 160 с.

21. Electric surfacing of wear resistant SHS-powder coating of working bodies of agricultural machines / A. V. Sobachkin, V. I. Yakovlev, M. V. Loginova, Ya. Dong, A. M. Guriev // Effect of External Influences on the Strength and Plasticity of Metals and Alloys : book of the International workshop articles / ed. by M. D. Starostenkov. - Barnaul : AltSTU, 2015. - P. 104.

22. Nicholls J. R. Designing oxidation-resistant coating // JOM. - 2000. - Vol. 52, no. 1. P. 28-35. - DOI: 10.1007/s11837-000-0112-2.

23. Keddam M., Chegroune R. A model for studying the kinetics of the formation of Fe2B boride layers at the surface of a gray cast iron // Appl. Surf. Sci. - 2010. - Vol. 256, iss. 16. P. 5025-5030. - DOI: 10.1016/j.apsusc.2010.03.048.

24. Гурьев А. М., Иванов С. Г., Мэй Ш. Структура боридных покрытий на сталях различного назначения // Электротехника. Энергетика. Машиностроение : сборник научных трудов I Международной научной конференции молодых ученых. - 2014. - C. 199-201.

25. Matijeviж B. Evaluation of Boride Layer Growth on Carbon Steel Surfaces // Metal Science and Heat Treatment. - 2014. - Vol. 56. - P. 269-273. - DOI: 10.1007/s11041-014-9744-7.

26. Гузанов Б. Н., Косицин С. В, Пугачева Н. Б. Упрочняющие защитные покрытия в машиностроении. - Екатеринбург : УрО РАН. - 2004. - 242 с.

27. Филиппов М. А., Косицина И. И., Гервасьев М. А. Упрочнение и защита поверхности металла. - Екатеринбург : УрО РАН. - 2012. - 234 с.

28. Pugacheva N. B. Current trends in the development of heat-resistant coatings based on aluminides of iron, nickel and cobalt // Diagnostics, Resource and Mechanics of Materials and Structures. - 2015. - Iss. 3. - P. 51-82. - DOI: 10.17804/2410-9908.2015.3.051-082. URL: https://www.dream-journal.org/DREAM_Issue_3_2015_Pugacheva_N._B._051_082.pdf

29. Denisyuk A. K., Zagulyaeva S. V., Potutkina E. N. Structure of borided layers in carbon steel // Russian Engineering Research. - 2011. - Vol. 31. - P. 191-192. - DOI: 10.3103/S1068798X11020080.

30. Анализ влияния природы легирующих элементов в высоколегированных сталях на процессы комплексного многокомпонентного диффузионного борирования / М. А. Гурьев, А. М. Гурьев, А. Г. Иванов, С. Г. Иванов // Международный журнал прикладных и фундаментальных исследований. - 2010. - № 5. - С. 155-157.

31. Pugacheva N. B., Bykova T. M., and Trushina E. B. The steel-basis structure influence on the diffuzion boride coatings structure and properties // Uprochn. Tekhnol. Pokryt. - 2013. No. 4. - P. 3-7.

32. Effects of electrochemical boriding process parameters on the formation of titanium borides / A. Kilic, G. Kartal, M. Urgen, S. Timur // Surface Engineering and Applied Electrochemistry. - 2013. - Vol. 49, iss.2. - P. 168-175. - DOI: 10.3103/S1068375513020051.

33. Быкова Т. М. Влияние химического состава стали на структуру и свойства диффузионных боридных покрытий : дис. канд. техн. наук : 05.16.09. - Екатеринбург, 2016. - 164 с. 
34. Афанасьев А. А., Погонин А. А., Стативко А. А. Микротвердость диффузионных боридных слоев на сталях как качественный показатель поверхности // Вестник Харьковского национального автомобильно-дорожного университета. - 2008. - № 42. - С. 65-67.

35. Диффузионные боридные покрытия на железе, сталях и сплавах : монография / В. Н. Гадалов, А. С. Борсяков, В. Г. Сальников, Б. Н. Квашнин, Д. Н. Романенко, А. В. Ляхов. - Москва : Курс, 2012.

36. Влияние толщины покрытия на восстановление деформации при микроиндентировании поверхности подложки / И. Ю. Гончаров, О. А. Дручинина, Н. В. Камышанченко, М. Г. Ковалева, А. Я. Колпаков // Деформация и разрушение материалов. -2006. - № 5. C. $30-34$.

37. Пугачева Н. Б., Быкова Т. М. Строение и свойства градиентных боридных покрытий // Механика, ресурс и диагностика материалов и конструкций : сборник материалов. - 2016. C. 210-211.

38. Особенности усталостного разрушения поверхностно-упрочненных материалов / А. Г. Тюрин, Н. В. Плотникова, В. Г. Буров, С. В. Веселов, Е. Д. Головин // Научный вестник Новосибирского государственного технического университета. - 2007. - № 4. - С. 93-98.

39. Investigation of mass transfer duaring tribological interaction of alloyed steels / N. B. Pugacheva, S. V. Pavlyshko, E. B. Trushina, A. N. Zamyatin // Journal of Friction and Wear. - 2012. - Vol. 33, no. 3. - P. 208-216. - DOI: 10.3103/S1068366612030099.

40. Денисюк А. К., Загуляева С. В., Потуткина Е. Н. Влияние условий борирования на структуру и твердость борированного слоя // Упрочняющие технологии и покрытия. - 2012. № 2. - С. 29-31.

41. Лукьянонов Д. С. Влияние остаточных макронапряжений на процесс зарождения квазихрупких трещин в термодиффузионных покрытиях // Успехи современного естествознания. - 2011. - № 7. - С. 266-267.

42. Химико-термическая обработка металлов и сплавов : справочник / Г. В. Борисенок, Л. А. Васильев, Л. Г. Ворошнин и др. - М. : Металлургия, 1981. -424 с.

43. Пугачева Н. Б., Мазаева Е. С. Защитные совйства высокотемпературных комбинированных покрытий // Физика и химия обработки материалов. - 2001. - № 4. - С. 82-90.

44. Failure modes in plazma-spraed thermal barrier coatings / K. W. Schlichting, N. P. Padture, E. H. Jordan, M. Gell // Materials Science and Engineering. - 2003. - Vol. A342. P. 120-130. - DOI: 10.1016/S0921-5093(02)00251-4. 